\title{
Three Domains of Project Organising
}

\author{
Graham M Winch \\ Centre for Infrastructure Development \\ Manchester Business School \\ graham.winch@mbs.ac.uk \\ To Appear in: International Journal of Project Management \\ 10.1016/j.ijproman.2013.10.012
}

\begin{abstract}
It has become axiomatic in research on project organising that projects are temporary organisations. Yet there are a number of challenges to this axiom: research on matrix organisation, the embeddedness of projects in project ecologies, and projectification all emphasise the relationship of the project to permanent organisations. Similarly, research on project-based firms and owner organisations which are relatively permanent challenges this axiom. This paper develops a conceptual framework which defines three domains of project organising: project-based firms; projects and programmes; and owners and operators as its principal theoretical contribution. This conceptual framework draws our attention to two important new areas for future research in project organising. The first is at the interfaces between the three domains of project organising: commercial, resourcing, and governance. The second is on project organising as temporary configurations of permanent organisations in coalitions to deliver particular outputs.
\end{abstract}

Key Words

Temporary organisation, project-based firm, owners and operators, project governance, commercial management 


\section{Three Domains of Project Organising}

Introduction

It has become axiomatic in the literature on project forms of organising that project organising is temporary. The aim of this paper is to challenge that axiom and to argue that most project organising is done by relatively permanent forms of organisation. We will further argue that the conflation of project organising with temporary organising has limited the development of research in the field. We develop our argument through a critical review of the literature, focusing on key contributions which have developed distinctive positions relevant to our argument rather than claiming to be comprehensive. First, we will review the literature on temporary organisation, showing how it has created an impressive intellectual momentum. We will then turn to a more recent body of literature which provides an important, but largely unnoticed, theoretical challenge to the literature on temporary organising - the literature on project-based firms. We next turn to an important gap left by these two literatures which has received relatively little attention both empirically and theoretically the role in project organising of the owners and operators of the outputs created by the project.

On the basis of these three reviews we develop and present a conceptual framework for the project organising research field. Conceptual frameworks help to "organize empirical observations by using coherent and meaningful frameworks. Such frameworks allow scholars to make sense of the field and understand its boundaries, major findings, and challenges” (Shapira 2011: 1314). They provide the basis for theory development and so the conceptual framework developed in this paper is its principal theoretical contribution. The field is here defined as the scope of the International Journal of Project Management with an emphasis on organisational aspects rather than tools and techniques. This conceptual framework also allows us to suggest that some of the most interesting research challenges in project organising lie at the interfaces between the three domains of project organising and reveals the importance of a newly emerging organisational form that sits at the interface of all three domains - programme partners. Implications for theory in project organising and suggestions for further research follow. 
Project Organising as Temporary Organising

The Project Management Institute in the $5^{\text {th }}$ Edition of its Project Management Body of Knowledge provides an authoritative statement of the temporary organising axiom, defining a project as "a temporary endeavor undertaken to create a unique product, service or result". This statement is supported by the organisational research literature over the past 50 years. Goodman and Goodman examined theatrical productions as examples of temporary organisations defined as a "set of diversely skilled people working together on a complex task over a limited period of time” (1976: 494). In its focus on the execution by individuals of time-limited and complex tasks and the associated human resource issues, this pioneering research influenced a considerable body of later research in the entertainment sector, particularly film. Jones (1996) examined the ways in which careers developed in the context of multiple deployments in temporary film organisations, while DeFillippi and Arthur (1998) show how such temporary organisations raise important challenges to the dominant precepts of organisation theory.

More recent research has deepened the insights around the relationships between tasks, people and their development. Bechky (2006) developed on the basis of intensive ethnographic work in the film industry a more nuanced analysis, showing how particular deployments and inter-personal relationships were indeed temporary, but also how such relationships could only be negotiated on the basis of more long-lasting notions of role in the context of expectations of future interactions on other projects. Kellogg et al (2006) turn their attention to the ways in which cross-boundary coordination is achieved in "heterarchic" organizations such as an internet start-up company, creating a "trading zone” which enables project coordination in fast-paced, temporary and volatile conditions.

A second contribution to the temporary organising axiom has been work on engineering and construction projects. Drawing on research on the Apollo programme, Wilemon and Gemmill (1971) and Wilemon (1973) focused on interpersonal conflict within temporary project organisations. Drawing on interviews with NASA project and technical personnel, they argued that the temporary nature of project organisations placed particular demands on the project managers because they had to 
interface with multiple parties to ensure mission success, and that their ability to subtly deploy power was critical. Bryman et al (1987) provided a thorough review of the literature to date and then applied the notion of temporary system to a construction project. They found themes that were already familiar from the literature such as the stress and interpersonal conflict inherent in temporary organisations and emphasised the important of the time dimension in the management of such organisations.

Implicit in much of the early literature on engineering and construction projects is a notion of a distinctive project life-cycle as it progresses through time towards its predetermined end, although it is typically not the focus of the analysis offered. Morris (1994) and Turner (2009) present a variety of different life-cycles garnered from different sources, while Wheelwright and Clark (1992) present different types of "funnel" for new product development projects. In some sectors, such as defence acquisition, life-cycle models can attain the status of law. The majority of life-cycle models appear to focus on specifying key decision points, an approach that has now widely disseminated in the shape of stage-gate project process models (Cooper, 1993).

Despite a significant body of organisation and management research on temporary project organisations, it remained rather fragmented, and was certainly failing to meet Wilemon and Cicero's (1970, 282) aspirations for a "general theory of project management”. Lundin and Söderholm (1995) drew generally on this research tradition to develop their "theory of the temporary organisation". They argued for an action-based theory with the project process articulated in terms of basic concepts of task, team, time and transition sequencing through four sequencing concepts denoting phases of the project. They thereby combined the concepts of the project as temporary organising and the project life-cycle. Packendorff (1995) picked up this theme, arguing that conceiving of the project as a temporary organisation was the way to move beyond the concept of the project as a delivery tool which pervades the professionally orientated research on the topic. In contrast, Turner and Müller (2003) argued that defining the project as a temporary organisation is entirely consistent with viewing the project as a delivery tool - or production function in their terms - and showed its deep roots in the mainstream professionally-orientated project management literature. Bakker (2010) provides a recent 
review of the literature on temporary organisational forms, showing how pervasive the association of project organising and temporary organising has become.

However, as the association of temporary organising with project organising steadily achieved axiomatic status, there were a number of other contributions that, in effect, challenged this association. The early work on engineering projects also identified the development of "matrix organisation" in which the temporary organisation was "superimposed upon the functional organization” (Wilemon and Cicero, 1970: 271), and therefore much attention was given to the boundary position of the project manager between the temporary and permanent organisations (Gaddis, 1959) and the conflict inherent in such a role. The theory of matrix organisation was developed by Galbraith (1970) in his work on Boeing and became part of the mainstream organisation theory on organisational coordination mechanisms (Mintzberg, 1979; authors, 1994). While matrix organisations were often characterised as unstable (e.g. Greiner and Schein, 1981), this is not the same as characterising them as temporary organisations.

Within the media sector, research attention was also turning to the relationship between the temporary and the permanent. While the work on the film industry did note in passing the geographical clustering of film production, Grabher’s (2002) work fully articulated the theoretical implications and again focused on the interdependencies between temporary organisations and permanent organisations. In a study of the London advertising industry, he identified the importance of the "project ecology" of a deep pool of expertise with strong interpersonal connections which could be mobilised on particular projects for clients. Complementary work on the Munich software cluster (Ibert 2004) showed how the linear notions of time in temporary project organisations are in tension with the more circular notions of time in permanent firms within the project ecology.

A third challenge to the dominance of the notion of temporary organisation came from the work on “projectification” as a process of change in permanent organisation. For instance, Midler (1995) shows how Renault evolved towards a project-based organisation for new product development over 30 years towards a more project-orientated organisation. Similarly, authors (2012) shows how a 
research laboratory managed its change from a functionally orientated organisation to a project orientated one. On this evidence, projectification is the process of change by the firm towards management by projects (Gareis, 1989; 2010) but it remains management by the firm of its projects rather than the creation of a shoal of temporary project organisations.

Our review of the literature on projects as temporary organisations has shown that the concept has deep roots in both the academic research literature and the evolving professionally-orientated literature over the last 50 years which have reinforced each other to the extent that project organising and temporary organising are now seen as synonymous by many. However, we have also identified other literature that, while happy to adopt the notion of temporary organising as a positioning for its contribution, subtly questions the characterisation of temporary organising as articulated by Lundin and Söderholm (1995). This is because the literatures on matrix organisation, project ecologies, and projectification all in different ways place the emphasis upon the interactions between the temporary project organisation and the permanent organisations that resource it. This implies doing more than merely acknowledging the context of the temporary organisation as Bakker (2010) does. Engwall (2003) argues that "no project is an island" and that the scope of analysis needs to be extended both temporally and organisationally with attention of the interface of the project to its "parent" organisation.

This paper aims to contribute to the development of a more holistic perspective on project organising that builds on the contribution of Lundin and Söderholm, while also developing the insights of Engwall (2003) to broader effect. However, before we turn to the next step of the argument, it is worthwhile addressing a definitional problem in the pervasive temporary/permanent dichotomy. One obvious problem with this distinction is that no organisation is permanent, so projects are temporary in only a relative sense and some "permanent" firms do not survive the projects on which they are working - the Wembley Stadium project was particularly notorious in this respect (authors, 2010). So, we suggest that the crucial distinction is not that the project organisation is temporary, but that it is determinate. That is, from the outset it is known by all participants that it will be terminated at some pre-agreed point in the future and that point becomes, fairly early in the project life-cycle, a deadline 
agreed by the parties to the project. Other types of organisations are, in contrast, indeterminate in that while they could disappear at any moment due to force majeur, they operate as going concerns without anticipation of termination at any particular point in time. This distinction also helps to clearly distinguish project organisations from the more diffuse category of all temporary organisations, many of which are not project organisations (Bresnen et al, 1987). We will therefore use "temporary" and "permanent" as shorthand for this distinction as we develop our argument. Following Engwall (2003), we will now turn to the "parent” organisations of projects - owners and operators.

Project Owners and Operators

Engwall's (2003) case focal organisation is an energy utility. Energy utilities earn their keep by generating and distributing energy to customers, both commercial and retail. None of this requires a project form of organisation. However, when utilities wish to either expand or upgrade their ability to deliver energy to customers, they typically engage in significant asset acquisition projects - hence the two embedded cases explored by Engwall. Energy utilities are therefore the owners and operators of energy networks, and intermittently invest in projects to develop those networks. These projects arise out of the ongoing business activities of the utility, and such projects are usually (excepting so-called "licence to operate" projects) the result of a strategic initiative by the firm. It is important to note that the "core business" (Kay, 1993) of an energy utility is not to build power stations or transmission networks, but to deliver energy to customers; thus the assets created by investment projects are the infrastructure by which energy is generated and transmitted and are only of value to the extent that they support that core business. One way of defining the core business of a firm is to use Porter's (1985) "value chain" concept to identify the "primary activities" of the organisation, while the development of infrastructure to enable those activities is part of the "support activities".

The role of permanent firms as owners and operators of infrastructure that enable the delivery of goods and services to customers on a continuing basis has important implications for project organising. In this perspective it is perceived inadequacies in the existing business infrastructure that 
generate investment projects such as those discussed by Engwall. These perceived inadequacies can arise from dilapidation (the hydroelectric power station case); the opportunity to take advantage of new technologies to improve the integrity of service delivery (the HVDC case); the need to expand capacity to meet demand (e.g. airports); or business opportunities offered by disruptive technologies (e.g. railways in the early $19^{\text {th }}$ century; mobile phone networks today); and many other dynamics.

Similarly the public sector and its agencies are the owners and operators - depending on the jurisdiction - of infrastructure to deliver transportation services (e.g. roads); health services (e.g. hospitals); education services (e.g. schools) and many others. Similarly, government is the sole source (in most jurisdictions) of demand for defence materiel. Even if a firm or government agency does not rely upon physical infrastructure to deliver goods and services to customers and citizens, information technology infrastructure is vital for the effective operation of most organisations (Duncan, 1995). The pervasive reliance of organisations on enterprise systems such as SAP is one example of this, but bespoke systems can also be important for competitive advantage. One example is Apple's iTunes infrastructure which links together all its innovative consumer products into a systemic whole and meets Barney’s (1991) VRIN criteria more clearly than any particular Apple product, many of which are presently being challenged in the market by companies such as Samsung.

In contrast to the extensive literature on temporary project organising, project organising by permanent owners and operators of business infrastructure - be it physical or information systems has received little explicit attention. Rather, much of the literature is generic in the sense that it appears to be applicable in the same say to both the project organisation and the owner organisation. For instance, across an influential set of reviews of the project management field, Söderlund (2004; 2011) does not identify any distinction between the temporary project organisation and the permanent organisation that owns the output being created. This is despite $(2004,187)$ posing the question "why do project organizations exist?” From an owner organisation perspective, the answer to this question would be "to develop strategically our business infrastructure". 
An important exception to this generalisation is a body of literature drawing on data from project benchmarking studies which emphasises the owner role. Independent Project Analysis (IPA) provides project benchmarking services in the engineering construction sector, working for clients such as international oil companies on the performance of their projects. This data set is confidential to those who are members, but a sub-set underpins the arguments in Merrow (2011) on megaprojects and the broader data set tells much the same story. This, in essence, is that contractors cannot do owner's work. "The contractor's job is to deliver a project as specified, on time and on budget. The owner's job is to specify the right project” $(2011,126)$. These results are supported by an analysis of Construction Industry Institute benchmarking data (Hui et al, 2008) which reports that construction owners who exhibit high 'owner dominance' tend to achieve better performance on their projects, where the construct is operationalised as the proportion of project activities performed by the owner. We now turn, therefore, to the suppliers to owners and operators of the resources required for projects and programmes.

Project Suppliers

Owners and operators do not usually undertake entire projects themselves; they typically hire permanent suppliers of project-related services which are usually organised as project-based firms, which “organize work around relatively discrete projects that bring particular groups of skilled staff together to work on complex, innovative tasks for a variety of clients and purposes (Whitley, 2006: 79). As Whitley makes clear, such firms as distinct, indeterminate legal entities are distinguished from "project-based organisations" defined as "organizational forms involved in the creation of temporary systems” (Sydow et al 2004: 1475) which are largely synonymous with the temporary organisations discussed above. As Merrow (2011) observes, the supplier plays a very distinctive role on the project in contrast to that of the owner. For these firms, projects are their core business (Kay, 1993). While there are many different kinds of project-based firm (Whitley, 2006), and some, such as film production companies (DeFillippi and Arthur, 1998) or special purpose vehicles for private finance projects are determinate in life expectancy, many are of considerable age and substance as suppliers to owners and operators such as the P-form organisation (Söderlund and Tell, 2009) specialising in 
supplying electrical generation and distribution assets to energy utilities. Unlike owners, which are located both in the public and private sectors depending on policy in the particular jurisdiction, suppliers are almost always in the private sector, although for the exception of a government laboratory providing contract research services to a number of different government departments see authors (2012).

One body of research on project-based firms has been concerned with innovation in suppliers of “complex product systems” such as flight simulators which are commissioned by "users” (owners and operators as defined above; airlines in this particular case) and supplied by "systems integrators" who draw on networks of specialised and other suppliers (Miller et al, 1995). Hobday (2000) goes on to argue that project-based organisations are the most appropriate for the efficient and effective supply of complex products and systems such as medical equipment to owners and operators. Further research on this theme has identified the project-based firm and its project capabilities as central to competitive advantage in high technology industries (Brady and Davies, 2004; Davies and Brady, 2000; Davies and Hobday, 2005). Similarly, Ethiraj et al (2005) identify the importance of project management capabilities in the performance of software services firms. This work is also important for identifying at least two very different types of project-based firm - the systems integrator that supplies and integrated asset to the owner/investor, and the specialist technology supplier which provides subsystems and often trades in proprietary technology.

Another body of work focused on project-based firms is on "project business" (Artto and Wikström, 2005; Cova et al, 2002) and different kinds of business models for project-based firms (Wikström et al, 2010; Kujala et al, 2010). Although the bibliometric study which underlay the initial formulation of the concept cast its net widely, the case study research through which it is being developed has focused on sectors such as shipbuilding (Ruuska et al, 2013), metallurgical processing equipment (Mutka and Aaltonen, 2013), and automation equipment (Ahola et al, 2013). The research, therefore, covers firms in many of the same sectors as the work on complex product systems (Hobday, 1998) and shares its definition of the project-based firm as a supplier to owners and operators in sectors such 
as shipping and resource extraction. As a result, moves have been made towards a joint perspective (Artto et al, 2011).

Project Organising: An Conceptual Framework of the Field

We have now reviewed three bodies of literature that address important issues in project organising. We have reviewed the extensive research on temporary organising which assumes either implicitly or explicitly that the project organisation is temporary; this assumption has become axiomatic in the project management discipline for both research and practice. We went on to review two other bodies of literature that have pursued important lines of enquiry in the field of project organising. The first looks at the project-related activities of owners and operators of the (typically complex) products delivered by the project; the second looks at the project-based firms which supply the capability to do the project so that it can deliver value for the potential owner and operator. Both of these types of organisations are relatively permanent in the sense defined above. Figure 1 captures this perspective on the scope of project organising.

Figure 1; about here

The conceptual framework shows the three principal organisational types in the organisational field (DiMaggio 1991), of projects - the temporary project or programme; the relatively permanent owner and operator; and the relatively permanent project-based firm as supplier. We propose these as the three domains of project organising. Owners supply the capital resources to the project organisation as investors; project-based firms provide the human and material resources to the project organisation. As with many conceptual models, the most interesting areas are probably not the main circles identifying the three domains of project organising, but the interfaces between the domains in the Venn-like overlaps. Indeed, these interfaces supply some of the most interesting and currently challenging areas of research in project organising - governance, commercial and resourcing - so we turn to these seriatim. 
Permanent/permanent Interface: Owners and Project-based Firms

Turning first to the interface between the owner organisation (firm or public agency) we focus on the broad commercial relationship between the owner and its suppliers on the project (Lowe 2013; Turner 1995). Commercial relationships have received relatively little attention in the mainstream project organising literature despite their empirical prevalence, although in the construction management literature commercial issues are a pervasive concern (e.g. Pryke and Smyth 2006; authors, 2010). One issue with this literature is that the owner and operator becomes a "client"; that is the focus of attention is entirely on the owner and operator as a purchaser of services for the delivery of the project, rather than as a strategic actor in its own right, although see Boyd and Chinyio (2006) for a sustained attempt to broaden the perspective. While there are both important policy concerns regarding the role of clients in relation to the projects they promote (NAO 2009) and more recent research around the notion of the "intelligent client" (Aritua et al, 2009; 2011) this work remains focused on the owner and operator as client rather than attempting to relate the client role to the broader owner strategy. A rather different perspective has emerged from the interaction between the supply chain management literature and the complex product systems literature discussed above with the focus on procuring “complex performance” (Caldwell and Howard, 2010), yet this work does not address why owners and operators should wish to switch from procuring assets to procuring performance.

Economists have also paid attention to these issues, particularly to the selection of supplier firms. Auction theory has been influential in work on the design of bidding processes (Bajari et al, 2008; McAfee and McMillan, 1986; McAfee and McMillan, 1987; Samuelson 1986; Vickery 1961), as has game theory (Brown et al, 2010). However, this work remains tightly focused on the selection problem and does not address the wider issues in governance of the owner/supplier relationship. A broader perspective from economics which has the potential to locate relationships between suppliers and owners as part of the theory of the boundary of the firm is transaction cost economics (e.g. Williamson, 1996). There have been a number of applications of the transaction cost approach to buyer supplier relationships in a project context by both economists (e.g. Chang, 2013; Chang and 
Ive, 2007; Corts and Singh, 2004; Crocker and Reynolds, 1993; Masten et al, 1991; and organisation theorists (e.g. authors, 2010; Stinchcombe and Heimer, 1985). The perspective has also been extended to relationship between firms within the supply chain (González-Dias et al, 2000). However, this work has yet to be integrated into a more comprehensive theory of the firm and inter-firm relationships in a project context which would be required for a full transaction cost theory of economics and project organising, and there remain important questions regarding its value for understanding commercial relationships (Sanderson, 2012).

A very different commercial perspective focuses on the business models used by project-based firms discussed above to investigate the range of different services that suppliers can offer owner with respect to the projects they promote, in a broader perspective of "project marketing" (Cova et al, 2002). Kujala et al (2013) identify the range of services offered by suppliers from finance for the project through to through-life support for the asset delivered by the project, while Wikström et al (2009) show the ways in which supplier firms mature in the development of their service offer to owners. One weakness of this line of enquiry is that it is rather descriptive, and is not presently influenced by the theory of the firm, and the notion of business model it deploys does not take into account the financial aspects that are central to strategic management (Kay, 1993). A second is that the reasons why owners and operators are prepared to extend the range of services they buy remains under-researched. An important exception to this generalisation is the work on public/private partnerships which has paid significant attention to why public agencies are now buying a broader range of services from their suppliers (e.g. Hodge et al, 2010). A rapprochement with the theory of the firm (Milgrom and Roberts, 1992) from economics and both the positioning (Porter, 1985) and resource-based (Barney, 1991) views of the firm from strategic management would greatly enhance the literature on the project-based firm.

The commercial management and transaction costs literatures tend to approach commercial issues from the perspective of the owner, even if they, implicitly or explicitly, reduce the notion of owner and operator to that of client. The project marketing literature tends to approach commercial issues from the point of view of the supplier. However, central to transaction cost economics (Williamson, 
1996) is the nature of the relationships between firms - in our case between the owner and operator and its suppliers of project services. From this perspective, the commercial management literature needs to pay more attention to the dynamics of the relationships between firms. While the literature on partnering does indeed focus on the nature of relationships, it has tended to be normatively driven (Bresnen, 2007) and would warrant a more critical approach. At the same time, the project marketing literature needs to pay more attention to the reasons why owners and operators are changing the mix of services they procure from project-based firms.

Permanent/temporary Interface: Owners and Their Projects and Programmes

The relationship between owners and their projects is usefully summarised as the challenge of governance, or the processes by which owners and operators assure themselves that they have selected the most appropriate projects and that they are progressing as desired. Broadly speaking there are two largely separate literatures of relevance here. The first is that on project portfolio management. Owners and operators are the principal suppliers of financial resources to project organisations. Typically they do this out of operating surpluses or from loans secured as a floating charge on the business. An important exception to this generalisation is the use of "project finance" (Morrison, 2012) in which the loan is secured on the assets being generated by the project. However the finance is raised by the project promoting owner and operator, the capital budgeting process by which the available capital is allocated to viable projects is one of the most important strategic processes in any firm (Bower, 1970). There has, however, been relatively little recent work on how owners and operators allocate financial resources to projects with the important exception of work on the selection of transportation projects by the public sector. Flyvbjerg et al (1993) developed and analysed a data base of transportation projects which showed their chronic tendency to both overestimate benefits and underestimate costs. This suggests that project promoters were engaging in deception through "strategic misrepresentation", or the deliberate distortion of the investment appraisal process, or at the very least, suffered delusion from a more unconscious "optimism bias" in their investment appraisals (Flyvbjerg et al, 2009). Subsequent work has focused on the policy 
prescriptions which can improve the quality of investment appraisal (e.g. Flyvbjerg, 2013; Priemus et al, 2008; Williams et al, 2009).

The outcome of the capital budgeting process is the portfolio of projects selected for investment by the firm. From a financial perspective (Markowitz, 1952), the portfolio optimises the potential of the firm to maximise the returns on its investment capital. This approach has more recently developed into a real options perspective (Smit and Trigeorgis, 2009) in which investment projects can be conceptualised as options "safeguarding” (Gil, 2007) future investments, and can be complemented by analytic hierarchy process techniques (Angelou and Economides, 2008). However, from a resource-based view of the firm (Barney, 1991) these financial approaches are limited because finance (investment capital) is only one of the resources required for investment projects and, in some ways, it is the most readily available. Penrose (1995) argues that the principal constraint to the growth of the firm is managerial capability; firms typically grow either by exogenous investment in mergers and acquisitions or endogenous investment in new products and services and the infrastructure to get them to market. Thus the ability of the firm to manage its investment projects is a major constraint on the size of its investment portfolio and hence its ability to grow independently of its ability to access the required capital.

Project portfolio management therefore becomes an important element in the strategic management of owner and operators (Jonas, 2010; Killen et al, 2012). However, project portfolios tend to be incomplete (Blichfeldt and Eskerod, 2008) and fall short of the widely accepted definition of "a group of projects that are carried out under the sponsorship and/or management of a particular organisation” (Archer and Ghasamzadeh, 1999: 208). This is the challenge of "skunk works" (Stalk and Hout, 1990) where projects are promoted by enthusiastic managers outside the mandated resource allocation processes. Kidder's (1982) case study of the Eagle project provides one (successful) example, but the risk is high that skunk works generate misallocation of resources to unviable projects.

There is now a growing empirical literature on the organisation of project portfolio management (e.g. Petit 2012; Teller et al 2012) and in her recent review of this sub-field, Martinsuo (2013) calls for 
more studies which move the research agenda on from organisation to practice - to what project portfolio managers actually do. Perhaps the best source we have on practice remains Bower, and his conclusion $(1970,303)$ that a project proposal "must be regarded as a 'move' in a complicated game with economic, organizational and interpersonal implications” remains highly relevant for research on project organising. Bad projects within the portfolio remain hard to kill (Royer, 2003) and much more research is required on effective governance.

The second is the challenge of project assurance (NAO, 2010). At the core of most project assurance processes is some kind of stage-gate process (Cooper, 1993) which addresses the "who, when, what" questions (authors 2010) of who should make decisions on the progress of project when in the lifecycle on the basis of what information. This can be complemented by the three "lines of defence" for assurance - effective project controls by the client project team; internal assurance functions independent of the project team; and external audit (Hone et al, 2011). Williams et al (2010) provide case studies of assurance on government projects, demonstrating the rather mixed implementation of assurance arrangements, while Young et al (2012) show how limited the impact of formal assurance procedures has been on government projects. The link between project portfolio management and assurance lies in the project management office (PMO) (Aubry et al 2010; Hobbs et al 2008) or more specifically, the "project portfolio management office” (Unger et al 2012) in its “controller” function.

One problem with formalised procedures such as stage gates is that closing the gate on the project can be much the same as closing the stable door once the horse has bolted; similar problems apply to essentially lagging indicators such as the "lines of defence" of formal assurance. A different approach is to pay attention to early warning signs of difficulties emerging on the project, especially "gut feelings” (Williams et al, 2012). Grenny et al (2007) have argued that there is a "crisis of silence” on projects as difficult conversations are not had by those responsible for the project. The importance of the owner's project manager regularly walking the project - particularly when it is on site - has also been identified (Hopkins, 2012). All this effort at oversight of the project requires that the owner's project management team is adequately staffed - understaffed owner teams are a major source of project failure (Merrow, 2011). 
Temporary/permanent Interface: Project-based Firms and their Projects

Suppliers are procured by owners acting as clients to supply human and material resources to the investment projects that they promote. Few owners retain the human resources in house for the delivery of their projects beyond their own project management capabilities, and they typically fail to retain enough of these (Merrow, 2011). For the delivery of their projects they rely on the resources supplied to them by project-based firms. Engwall and Jerbrant (2003) noted nearly 10 years ago how little research there had been on the resource allocation problem, and that observation remains largely true today even though Turner has moved to defining a project as "a temporary organisation to which resources are assigned to do work to deliver beneficial change” (2009: 2). Even project scheduling techniques that explicitly take into account resources such as critical chain (Goldratt, 1997) are of recent development and are still not diffused widely - project planners still tend to assume that resources are infinite when scheduling projects (authors, 2010).

Human resources lie at the heart of the issues here (Huemann et al, 2007). Engwall and Jerbrant (2003) show how different projects in a supplier of signalling systems compete with each other for human resources - here the crucial issues are the interfaces between projects as managers of the project-based firm juggle their human resources between projects. This can lead to problems of “project overload” (Zika-Viktorsson et al, 2006) as human resources are stretched between projects. However, it should be noted that these overload problems are not always a function of the external workload, but can also be generated by poor management of the available human resource pool by project-based firms (Bayer and Gann, 2006).

While the resourcing of individual projects by the project-based firm remains a challenge which has received relatively little research attention, a longer term issue which has received even less attention is "maintaining the resource base” (authors, 2000). If the project-based firm is the principal source of the human and material resources required by the project, then it needs to give attention to the renewal of those resources through training and innovation respectively. The episodic nature of project work tempts project-based firms to rely heavily on a casualised workforce of both technical professionals 
and craft workers which offers high flexibility for both employer and worker - this arrangement is at the heart of the project ecology (Grabher, 2002). However, such casualisation can seriously undermine the development and renewal of skills (authors, 1998). While the workers are typically highly skilled when they enter the project ecology, the driven nature of such labour markets (Evans et al, 2004) leaves little time out for the renewal of those skills.

Similarly, project-based firms face significant difficulties in innovation (Acha et al, 2005; Gann and Salter, 2000; Scarborough et al, 2004) ) - that is they find it difficult to develop novel solutions to the problems owners and operators have in their investment projects whether those are generated by new opportunities, desires to reduce budget and schedule, or regulatory challenges. The episodic nature of projects and the decentralised nature of project-based firms makes traditional centralised approaches to R\&D difficult and worsen the problems of learning from projects. An important opportunity for innovation in project-based firms is "base-moving projects" (Brady and Davies, 2004; Davies, 2004) where owners and operators demand new capabilities from their suppliers which can be developed into repeatable solutions for other projects (Davies and Brady, 2000; Prencipe and Tell, 2001), while communities of practice play a vital role in sharing learning (Lindkvist, 2005).

From a project organising perspective, the project-based firm is the holder of the resources required by the project organisation to deliver the assets desired by the owner and operator. Although there has been important work in understanding the nature and evolution of the project-based firm (Davies and Hobday, 2005; Whitley, 2006), further work is required on how it deploys its operational capabilities on projects and balances them across projects. This suggests that a rather different concept of project portfolio is required from that discussed above for owners and operators. For the latter the portfolio is essentially financial; for the project-based firm it is essentially operational. Further work is also required on the dynamic capabilities of project-based firm in terms of how they seize new opportunities while maintaining the existing resource base. 
Multiple Interfaces: The Programme/project Manager.

At the heart of figure 1 is the project or programme manager, but rather than being the apotheosis of Gaddis’ (1959) “man in the middle”, it is rather a shorthand for some relatively complex organising in its own right. Many projects have multiple people with the role of project manager working on them, and multiple teams managing the project. For instance, the Tate Modern project had three different people with the title "Project Director" each working for a different permanent organisation (authors, 2010).

An important issue here which has not received significant research attention is the challenge faced by owners who only make intermittent investments which means that they cannot effectively develop adequate in-house project capabilities as recommended by Merrow (2011). Here the "delivery partner” (London 2012 Olympics) or “programme partner” (London Crossrail) plays a vital role. The London 2012 delivery partner was a joint venture of three project-based firms which undertook both programme and project management functions for the delivery of the Olympic venues (Hone et al, 2011) selected through a "competitive dialogue” procedure (Cornelius et al, 2011) and answerable to the Olympic Delivery Authority, an agency of the UK government. The delivery partner then procured and managed the suppliers for the different facilities and the cross-programme packages.

Project Organising as Temporary Configurations of Permanent Organisations

Figure 1 implies a multi-organisational perspective on project organising. Horwitch and Prahalad (1981) identified "multi-organisation enterprise" as the new strategic frontier, while Cherns and Bryant (1984) defined a project as a "temporary multiorganization" and authors (1989) identified "project coalitions" of firms on projects. In combination with the analysis above, this suggests that project organising is best seen as a configuration of permanent organisations coming together to form a temporary coalition to deliver a particular outcome. These organisations bring different kinds of resources to the project - finance (usually the owner), and various kinds of technical and managerial skills (usually project-based firms). This can be the basis of a new and challenging research agenda for project organising (Jones and Lichtenstein, 2008) which acknowledges the temporary nature of 
project organisations, the permanent nature of the organisations that resource those temporary organisations, and their mutual embeddedness in wider socio-economic contexts. One way of theorising is indicated by research on Connecting for Health, one of the world's largest IS infrastructure projects drawing on neo-institutoinal theory and the concept of the "organisational field” of the programme (Currie 2012; Currie and Guah 2007).

At the project configuration level, one highly appropriate research methodology is social network analysis (Brass et al, 2004) focusing on either inter-organisational (Pryke, 2004) or inter-personal (Pauget and Wald, 2013) level relations. At the inter-organisational level, we propose a focus on the interfaces between the three types of organisations: specifically, governance for the owner/project interface; commercial for the owner/supplier interface, and resourcing for the supplier/project interface. At the organisational level, the research on the temporary project and programme management is arguably now mature; that on the project-based firm is maturing although a greater level of theoretical sophistication would be welcome, while that on the owner and operator is relatively immature and does warrant greater attention than it has received to date.

One important aspect of the Lundin and Söderholm (1995) perspective on temporary project organising is the link between the project organisation and the project life-cycle. There has been little work on the implications for temporary project organising during movement through the life cycle; exceptions include Thamain and Wilemon (1975) on how power dynamics vary through the project life-cycle and Morris' discussion (1994) of “matrix swing”. There is even less work on how project configurations change through the life-cycle. Authors (2010) uses transaction cost analysis to explain theoretically how governance arrangements between owners and suppliers shift, but there is little empirical work on this. Similarly, assurance arrangements will change as the project progresses. For instance owner project manager site tours have little relevance early in the project; later in the life cycle they are an important element of assurance, particularly in relation to Quality Environment Safety and Health (QUENSH) issues (authors, 2010; Hopkins, 2012).

Concluding Thoughts 
The principal contribution of this paper has been to articulate a conceptual framework (Shapira 2011) of the project organising field around three domains - the temporary project/ programme organisation and the two permanent organisations of owner and operator and project-based firm. We have also suggested that the contemporary focus on projects as temporary organisations has diverted attention from the permanent organisations that provide temporary organisations with financial resources (owners and operators) and supply human and material resources (project-based supplier firms). In particular, relatively little attention has been give in research on project organising to the interfaces between the temporary organisation and the two different types of permanent organisation that configure any project. We have proposed the conceptual framework in figure 1 as one way of capturing the full range of the research field of project organising and suggested that we need more research at the interfaces between the three domains, particularly those of assurance and resourcing. 
References

Authors

Acha, V., Gann, D.M., and Salter, A.J., (2005). Episodic Innovation: R\&D Strategies for Projectbased Environments. Industry and Innovation. 12, 255-281.

Ahola, T., Kujala, J., Laaksonen, T., and Aaltonen, K. (2013). Constructing the Market Position of a Project-based Firm. International Journal of Project Management. 31, 355-365.

Angelou, G.N., and Economides, A.A. (2008). A Decision Analysis Framework for Prioritizing a Portfolio of ICT Infrastructure Projects. IEEE Transactions on Engineering Management. 55, 479-495.

Archer, N.P., and Ghasemzadeh, F. (1999). An Integrated Framework for Project Portfolio Selection. International Journal of Project Management. 17, 207-216.

Aritua, B., Male, S., and Bower, D. (2009). Defining the Intelligent Public Sector Construction Client. Proceedings and the Institution of Civil Engineers: Management Procurement and Law. 162, 75-82.

Aritua, B., Male, S., Bower, D., and Madter, N. (2011) Competencies for the Intelligent Public Sector Construction Client. Proceedings and the Institution of Civil Engineers: Management Procurement and Law. 164, 193-201.

Artto, K., Davies, A., Kujala, J., and Prencipe, A. (2011). The Project Business: Analytical Framework and Research Opportunities. In Morris, P. Pinto, J. and Söderlund, J. (eds.) The Oxford Handbook of Project Management. Oxford, Oxford University Press (pp 133-153).

Artto, K., and Wikström, K. (2005). What is Project Business? International Journal of Project Management. 23, 343-353.

Aubry, M., Müller, R., Hobbs, B., and Blomquist, T. (2010) Project management offices in transition. International Journal of Project Management. 28, 766-788

Bajari, P., McMillan, R., and Tadelis, S. (2008). Auctions versus Negotiations in Procurement: An Empirical Analysis. Journal of Law, Economics and Organisation. 25, 372-399. 
Bakker, R.M. (2010). Taking Stock of Temporary Organizational Forms: A Systematic Review and Research Agenda. International Journal of Management Reviews. 12, 466-486.

Barney, J. (1991). Firm Resources and Sustained Competitive Advantage. Journal of Management. 17 99-120.

Bayer, S., and Gann, D. (2006). Balancing Work: Bidding Strategies and Workload Dynamics in a Project-based Professional Service Organisation. Systems Dynamics Review. 22, 185-211.

Bechky, B.A. (2006). Gaffers, Gofers and Grips: Role-based Coordination in Temporary Organizations. Organization Science. 17, 3-21.

Blichfeldt, B.S., and Eskerod, P. (2008). Project Portfolio Management - There's More to It than what Management Enacts. International Journal of Project Management. 26, 357-365.

Bower, J.L. (1970). Managing the Resource Allocation Process: A Study of Corporate Planning and Investment. Boston MA, Division of Research, Harvard Business School.

Boyd, D. and Chinyio, E. (2006). Understanding the Construction Client. Oxford, Blackwell.

Brady, T. and Davies, A. (2004). Building Project Capabilities: From Exploratory to Exploitative Learning. Organization Studies. 25, 1601-1621.

Brass, D.J., Galaskiewicz, J., Greve, H.R., and Tsai, H. (2004). Taking Stock of Networks and Organizations: A Multilevel Perspective. Academy of Management Journal. 47, 795-817.

Bresnen, M. (2007). Deconstructing Partnering in Project-based Organisation: Seven Pillars, Seven Paradoxes and Seven Deadly Sins. International Journal of Project Management. 25, 365-374.

Brown, T.L., Potoski, M., and van Slyke, D.M. (2010). Contracting for Complex Products. Journal of Public Administration Research and Theory. 20, 41-58.

Bryman, A., Bresnen, M., Beardsworth, A.D., Ford, J. and Keil, E.T. (1987). The Concept of the Temporary System: The Case of the Construction Project. Research in the Sociology of Organizations. 5, 253-283.

Caldwell, N., and Howard, M. (eds.) (2010). Procuring Complex Performance: Studies of Innovation in Product-Service Management. London: Routledge. 
Chang, C-Y. (2013). Understanding the Hold-up Problem in the Management of Megaprojects: The Case of the Channel Tunnel Rail Link Project. International Journal of Project Management. 31, 628-637.

Chang C-Y., and Ive, G. (2007). The Hold-up Problem in the Management of Construction Projects: A Case Study of the Channel Tunnel. International Journal of Project Management. 25, 394404.

Cherns, A. B., and Bryant, D.T. (1984). Studying the Client's Role in Construction Management. Construction Management and Economics. 2, 177-184.

Cooper, R.G. (1993). Winning at New Products: Accelerating the Process from Idea to Launch ( $2^{\text {nd }}$ ed). Reading MA, Perseus Books.

Cornelius, M., Fernau, J., Dickinson, P., and Stuart, M. (2011). Delivering London 2012: Procurement. Proceedings of ICE: Civil Engineering. 164, 34-39.

Corts, K.S., and Singh, J. (2004) The Effect of Repeated Interaction on Contract Choice: Evidence from Offshore Drilling. Journal of Economics and Organization. 20, 230-260.

Cova, B., Ghauri, P., and Salle, R. (2002). Project Marketing: Beyond Competitive Bidding. Chichester, Wiley.

Crocker, K.J., and Reyonds, K.J. (1993). The Efficiency of Incomplete Contracts: An Empirical Analysis of Air Force Engine Procurement Rand Journal of Economics. 24, 126-146.

Currie, W. L. (2012). Institutional Isomorphism and Change: The National Programme for IT - 10 Years On. Journal of Information Technology. 27, 236-248.

Currie, W. L. and Guah, M.W. (2007). Conflicting Institutional Logics: A National Programme for IT in the Organisational Field of Healthcare. Journal of Information Technology. 22, 235-247.

Davies, A. (2004). Moving Base into High-value Integrated Solutions: A Value Stream Approach. Industrial and Corporate Change. 13, 727-756.

Davies, A., and Brady, T. (2000). Organizational Capabilities and Learning in Complex Product Systems: Towards Repeatable Solutions. Research Policy. 29, 931-953.

Davies, A., and Hobday, M. (2005). The Business of Projects: Managing Innovation in Complex Products and Systems. Cambridge, Cambridge University Press. 
DeFillippi, R.J., and Arthur, M.B. (1998). Paradox in Project-based Enterprise: The Case of Film Making. California Management Review. 40, 125-139.

DiMaggio, P.J. (1991). Constructing an Organizational Field as a Professional Project: U.S. Art Museums 1920-1940. In: W.J. Powell and P.J. DiMaggio (eds.) The New Institutionalism in Organizational Analysis. Chicago, University of Chicago Press. 267-292.

Duncan, N.B. (1995). Capturing Flexibility of Information Technology Infrastructure: A Study of Resource Characteristics and Their Measure. Journal of Management Information Systems. 12, 37-57.

Engwall, M. (2003). No Project is an Island: Linking Projects to History and Context. Research Policy. 32, 789-808.

Engwall, M.. and Jerbrant, A. (2003). The Resource Allocation Syndrome: The Prime Challenge of Multi-project Management? International Journal of Project Management. 21, 403-409.

Ethiraj, S. K.. Kale, P.. Krishnan, M.S.. and Singh, J.V. (2005). Where do Capabilities Come from and How Do They Matter? A Study in the Software Services Industry. Strategic Management Journal, 26, 25-45.

Evans, J.A., Kunda, G., and Barley, S.R. (2004). Beach Time, Bridge Time, and Billable Hours: The Temporal Structure of Technical Contracting. Administrative Science Quarterly. 49, 1-38.

Flyvbjerg, B. (2013). Quality Control and Due Diligence in Project Management: Getting Decisions Right by Taking the Outside View. International Journal of Project Management. 31, 760-774.

Flyvbjerg, B., Bruzelius, N., and Rothengatter, W. (2003). Megaprojects and Risk: An Anatomy of Ambition Cambridge, CUP.

Flyvbjerg, B., Garbuio, M., and Lovallo, D. (2009). Delusion and Deception in Large Infrastructure Projects: Two Models for Explaining and Preventing Executive Disaster. California Management Review 51, 170-193.

Gaddis, P.O. (1959) The Project Manager. Harvard Business Review. May-June, 89-97.

Galbraith, J. R. (1970). Environmental and Technological Determinants of Organization Design. In: Lorsch, J.W. and Lawerence, P.R. (eds.) Studies in Organization Design. Homewood IL, IrwinDorsey pp 113-139. 
Gann, D.M., and Salter, A.J. (2000). Innovation in Project-based, Service-enhanced Firms: The Construction of Complex Products and Systems. Research Policy. 29, 955-972.

Gareis, R. (1989). Management by Projects: The Management Approach of the Future. International Journal of Project Management. 7, 243-249.

Gareis, R. (2010). Changes of Organizations by Projects. International Journal of Project Management. 28, 314-327.

Gil, N. (2007). On the Value of Project Safeguards: Embedding Real Options in Complex Products and Systems. Research Policy. 36, 980-999.

Goldratt, E.M. (1997) Critical Chain. Great Barrington, The North River Press.

Goodman, R.A., and Goodman, L.P. (1976) Some Management Issues in Temporary Systems: A Study of Professional Development and Manpower - the Theater Case. Administrative Science Quarterly. 21, 494-501.

González-Dias, M., Arruñada, B., and Fernández, A. (2000). Causes of Subcontracting: Evidence from Panel Data on Construction Firms. Journal of Economic Behavior and Organization. 42, 167-187.

Grabher, G. (2002). The Project Ecology of Advertising: Tasks, Talents and Teams. Regional Studies. 36, 245-262.

Greiner, L.E. and Schein, V.E. (1981). The Paradox of Managing a Project-Orientated Matrix: Establishing Coherence within Chaos. Sloan Management Review. Winter, 17-22.

Grenny, J., Maxfield, D., and Shimberg, A. (2007). How Project Leaders Can Overcome the Crisis of Silence. Sloan Management Review. 48, 46-52.

Hobbs, B., Aubry, M., and Thullier, D. (2008). The Project Management Office as an Organisational Innovation. International Journal of Project Management. 26, 547-555.

Hobday, M. (1998). Product Complexity, Innovation and Industrial Organisation Research Policy. 26, 689-710.

Hobday, M. (2000). The Project-based Organisation: An Ideal Form for Managing Complex Products and Systems. Research Policy. 29, 871-893. 
Hodge, G.A., Greve, C., and Boardman, A.E. (eds.) (2010). International Handbook on Publicprivate Partnerships. Cheltenham, Edward Elgar.

Hone, D., Higgins, D., Galloway, I., and Kintrea, K. (2011). Delivering London 2012: Organisation and Programme. Proceedings of ICE: Civil Engineering. 164, 5-12.

Hopkins, A. (2012). Disastrous Decisions: The Human and Organisational Causes of the Gulf of Mexico Blowout. Sidney, CCH Press.

Horwitch, M., and Prahalad, C.K. (1981) Managing Multi-organization Enterprises: The Emerging Strategic Frontier. Sloan Management Review. 22, 3-16.

Huemann, M., Keegan, A.E., and Turner, R.J. (2007). Human Resource Management in the Projectorientated Company: A Review. International Journal of Project Management. 25, 315-323.

Hui, P.P., Davis-Blake, A., and Broschak, J.P. (2008). Managing Interdependence: The Effects of Outsourcing Structure on the Performance of Complex Projects. Decision Sciences. 39: 5-31

Ibert, O. (2004). Projects and Firms as Discordant Complements: Organisational Learning in the Munich Software Industry. Research Policy. 33, 1529-1546.

Jonas D. (2010) Empowering project portfolio managers: How management involvement impacts project portfolio management performance. International Journal of Project Management. 28, 818-831.

Jones, C. (1996). Careers in Project Networks: The Case of the Film Industry. In: M.B. Arthur and D. Rousseau (eds.). The Boundaryless Career: A New Employment Principle for a New Organizational Era. New York NY, Oxford University Press. pp 58-75.

Jones, C., and Lichtenstein, B.B. (2008). Temporary Inter-organizational Projects: How Temporal and Social Embeddedness Enhance Coordination and Manage Uncertainty. In: S. Cropper, M. Ebers, C. Huxham, and P. Smith Ring (eds.) The Oxford Handbook of Inter-organizational Relations. Oxford, Oxford University Press. pp 231-255.

Kay, J. (1993) Foundations of Corporate Success. Oxford, Oxford University Press.

Kellogg, K.C., Orlikowski, W.J., and Yates, J. (2006). Life in the Trading Zone: Structuring Coordination Across Boundaries in Postbureaucratic Organizations. Organization Science 17, 22-44. 
Kidder, T. (1982). The Soul of a New Machine. Harmondsworth, Penguin.

Killen, C.P., Jugdev, K., Drouin, N., and Petit, Y. (2012). Advancing Project Portfolio Management Research: Applying Strategic Management Theories. International Journal of Project Management. 30, 525-538.

Kujala, J.. Ahola, T.. and Huikiri, S. (2013). Use of Services to Support the Business of a Projectbased Firm. International Journal of Project Management. 31, 177-189.

Kujala, S.. Artto, K.. Aaltonen, P.. and Turkulainen, V. (2010). Business Models in Project-based Firms - towards a Typology of Solution-specific Business Models International Journal of Project Management. 28, 96-106.

Lindkvist, L. (2005). Knowledge Communities and Knowledge Collectivities: A Typology of Knowledge Work in Groups. Journal of Management Studies. 42, 1189-1210.

Lowe. D. (2013). Commercial Management: Theory and Practice. Oxford, Wiley-Blackwell.

Lundin, R.A., and Söderholm, A. (1995). A Theory of the Temporary Organization. Scandinavian Journal of Management. 11, 437-455.

McAfee, P., and McMillan, J. (1986). Bidding for Contracts: A Principal-agent Analysis. Rand Journal of Economics. 17, 326-338.

McAfee, P., and McMillan, J. (1987). Auctions and Bidding. Journal of Economic Literature. 25 699738.

Markowitz, H. (1952). Portfolio Selection. Journal of Finance. 7, 77-91.

Martinsuo, M. (2013). Project Portfolio Management in Practice and in Context. International Journal of Project Management. 31, 794-803

Masten, S.E., Meehan, J.W., and Snyder, E.A. (1991). The Costs of Organization. Journal of Law, Economics and Organization. 7, 1-25.

Merrow, E. (2011). Industrial Megaprojects: Concepts, Strategies, and Practices for Success. Hoboken NJ: Wiley.

Midler, C. (1995) "Projectification" of the Firm: the Renault Case. Scandinavian Journal of Management. 11, 363-375. 
Milgrom, P., and Roberts, J. (1992) Economics, Institutions and Management. Upper Saddle River NJ, Prentice-Hall.

Miller, R., Hobday, M., Leroux-Demers, T., and Olleros, X. (1995). Innovation in Complex Systems Industries: The Case of Flight Simulation. Industrial and Corporate Change. 4, 363-400.

Mintzberg, H. (1979). The Structuring of Organizations Englewood Cliffs NJ, Prentice-Hall.

Morris, P.W.G. (1994). The Management of Projects. London, Thomas Telford.

Morrison, R. (ed.) (2012). The Principles of Project Finance. Farnham, Gower.

Mutka, S., and Aaltonen, P. (2013). The Impact of a Delivery Project’s Business Model in a Projectbased Firm. International Journal of Project Management. 31, 166-176.

NAO (2009). Commercial Skills for Complex Government Projects. London, National Audit Office.

NAO (2010). Assurance for High Risk Projects. London, National Audit Office.

Packendorff, J. (1995). Inquiring into the Temporary Organization: New Directions for Project Management Research Scandinavian Journal of Management 11, 319-333.

Pauget, B., and Wald, A. (2013). Relational Competence in Temporary Organizations: The Case of a French Hospital Construction Project Network. International Journal of Project Management. 31, 200-211.

Penrose E.T. (1995). The Theory of the Growth of the Firm ( $3^{\text {rd }}$ ed.). Oxford, Oxford University Press.

Petit, Y. (2012). Project portfolios in dynamic environments: Organizing for uncertainty. International Journal of Project Management. 30, 539-553.

Porter, M. (1985) Competitive Advantage: Creating and Sustaining Superior Performance. New York NY, Free Press

Prencipe, A. and Tell, F. (2001). Inter-project Learning: Processes and Outcomes of Knowledge Codification in Project-based Firms. Research Policy. 30, 1373-1394.

Priemus, H., Flyvbjerg, B., and van Wee, B. (eds.) (2008). Decision-making on Mega-projects: Costbenefit Analysis, Planning and Innovation Cheltenham, Edward Elgar.

Pryke, S. D. (2004). Analysing Construction Project Coalitions: Exploring the Application of Social Network Analysis. Construction Management and Economics. 22, 787-797. 
Pryke, S. D. and Smyth, H. (eds.) (2006) The Management of Complex Projects: A Relationship Approach. Oxford, Blackwell.

Royer, I. (2003) .Why Bad Projects are so Hard to Kill Harvard Business Review February, 48-56.

Ruuska, I., Ahola, T., Martinsuo, M., and Westerholm, T. (2013). Supplier Capabilities in Large Shipbuilding Projects. International Journal of Project Management. 31, 542-553.

Sanderson, J. (2012). Risk, Uncertainty and Governance in Megaprojects: A Critical Discussion of Alternative Explanations. International Journal of Project Management. 30, 432-443.

Scarborough, H., Swan, J., Laurent, S., Bresnen, M., Edelman, L., and Newell, S. (2004) Projectbased Learning and the Role of Learning Boundaries. Organization Studies. 25, 1579-1600.

Shapira, Z. (2011) “I’ve Got a Theory Paper - Do You?”: Conceptual, Empirical, and Theoretical Contributions to Knowledge in the Organization Sciences. Organization Science. 22, 13121321.

Smit, H.T.J., and Trigeorgis, L. (2009). Valuing Infrastructure Investment: An Option Games Approach. California Management Review. 51, 79-90.

Söderlund, J. (2004). Building Theories of Project Management: Past Research, Questions for the Future. International Journal of Project Management. 22, 183-191.

Söderlund, J. (2011). Pluralism in Project Management: Navigating the Crossroads of Specialization and Fragmentation. International Journal of Management Reviews. 13, 153-176.

Söderlund, J., and Tell, F. (2009). The P-form Organization and the Dynamics of Project Competence: Project Epochs in Asea/ABB, 1950-2000. International Journal of Project Management. 27, 101-112.

Stalk, G., and Hout, T.M. (1990). Competing Against Time: How Time-based Competition is Reshaping Global Markets. New York, Free Press.

Stinchcombe, A.L., and Heimer, C.A. (1985). Organization Theory and Project Management. Oslo, Norwegian University Press.

Sydow, J., Lindvkist, L., and DeFillippi, R. (2004). Project-Based Organizations, Embeddedness and Repositories of Knowledge: Editorial. Organization Studies. 25, 1475-1489. 
Teller, J., Unger, B.N. Kock, A., and Gemünden, H. G. (2012) Formalization of project portfolio management: The moderating role of project portfolio complexity. International Journal of Project Management. 30, 596-607.

Thamain H.J., and Wilemon D.L. (1975). Conflict Management in Project Life Cycles Sloan Management Review 16, 31-50.

Turner, J. R. (ed.) (1995) The Commercial Project Manager. London, McGraw-Hill.

Turner, J. R. (2009) The Handbook of Project-based Management. ( $3^{\text {rd }}$ ed.) New York, McGraw-Hill.

Turner, J.R., and Müller, R. (2003). On the Nature of the Project as a Temporary Organization. International Journal of Project Management 21, 1-8.

Unger, B.N., Gemünden, H.G., Aubry, M. (2012).The three roles of a project portfolio management office: Their impact on portfolio management execution and success. International Journal of Project Management. 30, 608-620.

Wheelwright, S.C., and Clark, K.B. (1992). Revolutionizing Product Development: Quantum Leaps in Speed, Efficiency, and Quality New York, Free Press

Whitley, R. (2006). Project-based Firms: New Organizational Form or Variations on a Theme? Industrial and Corporate Change. 15, 77-99.

Wikström, K., Artto, K.A., Kujala, J., and Söderlund, J. (2010). Business Models in Project Business International Journal of Project Management. 28, 832-841.

Wikström, K., Hellström, M., Artto, K., Kujala, J., and Kujala, S. (2009). Services in Project-based Firms - Four Types of Business Logic. International Journal of Project Management. 113-122. Wilemon, D.L. (1973). Managing Conflict in Temporary Management Systems Journal of Management Studies. 10, 282-296.

Wilemon, D.L., and Cicero, J.P. (1970). The Project Manager: Anomalies and Ambiguities Academy of Management Journal. 13, 269-282.

Wilemon, D.L., and Gemmill, G.R. (1971). Interpersonal Power in Temporary Management Systems. Journal of Management Studies. 8, 315-328.

Williams, T.M., Samset, K., and Sunnevåg, K.J. (eds.) (2009). Making Essential Choice with Scant Information: Front-end Decision Making in Major Projects. Basingstoke, Palgrave Macmillan. 
Williams, T.M., Klakegg, O.J., Magnussen, O.M., and Glasspool, H. (2010). An Investigation of Governance Frameworks for Public Projects in Norway and the UK. International Journal of Project Management. 28, 40-50.

Williams, T.M., Klakegg, O.J., Walker, D.H.T., Andersen, B., and Magnussen, O.M. (2012). Identifying and Acting on Early Warning Signs in Complex Projects. Project Management Journal. 43, 37-53.

Williamson, O.E. (1996). The Mechanisms of Governance. New York, Oxford University Press.

Young, R., Young, M., Jordan, E., and O’Connor, P. (2012). Is Strategy being Implemented through Projects? Contrary Evidence from a Leader in New Public Management. International Journal of Project Management. 30, 887-900.

Zika-Viktorsson, A., Sundstrom, P., and Engwall, M. (2006). Project overload: an Exploratory Study of Work and Management in Multi-project Settings. International Journal of Project Management. 24, 385-394. 


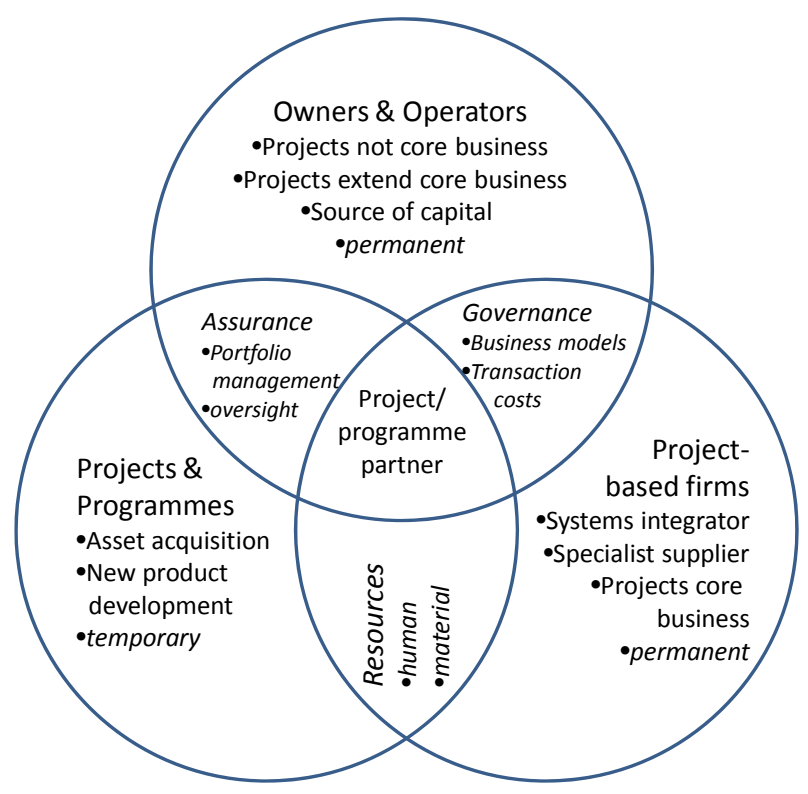

Figure 1: Three Domains of Project Organising 